\title{
Quality metrics in academic libraries: Striving for excellence
}

\author{
Leoné Tiemensma \\ Midrand Graduate Institute, South Africa
}

\begin{abstract}
Quality in academic libraries is a multi-dimensional construct. Quality management and quality assurance is part of measuring performance excellence. Libraries are services. To improve service quality, stakeholders' needs and expectations should be monitored and measured, shortfalls should be identified and addressed.

Some basic principles are common to all measurements, but quality metrics will focus on the unique nature and factors that could affect quality of academic library services. Measuring quality includes the resources, resource delivery, the service environment, the management and staff, and the different stakeholders. In the digital environment, the academic library also moves from collection to connection, with new demands and performance indicators. Both quantitative and qualitative measurements are required to evaluate the overall performance of the library. The ultimate goal of measurement is improving the "fitness for purpose" of the library.
\end{abstract}

Keywords: Academic libraries; Academic libraries - User satisfaction; Academic libraries - Evaluation; Performance assessment; Quality management; Quality assurance; Service quality

\section{Quality Management and Quality Assurance in academic libraries}

Understanding academic libraries requires understanding of higher education issues and needs. Academic libraries have a unique nature. The academic library functions in a larger context and one has to look how the library contributes to achieving the overall objectives of the parent institution.

Quality management involves the processes, activities and measures that contribute to the management of the quality of the products, service or other outputs from the organisation (Roberts \& Rowley 2004: 158). Quality assessment of the academic library is part of the total quality management (TQM) of the institution. TQM acknowledges that there is always room for improvement, that all organisations can and do fail, that employees make mistakes, and that we could all do better (Brophy 1997: 75). Quality management includes quality assurance and quality enhancement.

Quality assurance refers to the processes associated with ensuring that quality adheres to externally or internally set standards (Roberts and Rowley 2004:159). Quality assurance is a part of accrediting an institution. Education in South Africa is strictly monitored by the Department of Education, the South African Qualifications Authority (SAQA) and the CHE (Council for Higher Education). In South Africa the HEQC (Higher Education Quality Council), a sub committee of the CHE, is responsible for this issue. One of the audit criteria of the HEQC, is "Academic support services (e.g. library and learning materials, computer support services, etc.) adequately support teaching and learning needs and help give effect to teaching and learning objectives" (Blake 2008). Quality assurance in academic libraries is part of measuring performance excellence.

One of the objectives of the Bologna Declaration, a joint declaration of the European Ministers of Education, is the "Promotion of European co-operation in quality assurance with a view to developing comparable criteria and methodologies" (Bologna Declaration 1999), and the Standards and Guidelines for Quality Assurance in European Higher Education Area followed.

In the United Kingdom, the Research Assessment Exercise (RAE) assesses research quality. Researchers in the UK examined the relationship between library funding at UK universities and RAE ratings and found that higher funding of an academic library was associated with higher RAE ratings (Haddow 2007: 32). Strong research universities had well-supported libraries.

In Australia, a new funding model for research in Australian higher education institutions, the Research Quality Framework (RQF), impacts on academic libraries (Haddow 2007: 26-29). This model creates high demand for assistance from library staff on various levels.

Quality management in academic libraries thus has various dimensions:

> Accreditation by external bodies. Academic libraries are subject to formal quality audits and quality assurance processes; 
Achieving a quality of service that contributes to the institution's mission, vision, aims and objectives;

$>$ Achieving a quality of service that satisfies the research and information needs and expectations of academic and non-academic staff, undergraduate and postgraduate students, and university management;

$>$ Library management - How the service is provided. Operating in an effective manner with regards to, for example, staff, space and facilities, resources, acquisitions, access, availability, circulation, finances and information technology.

Quality management operates at different levels of the institution and the purpose is quality enhancement and providing accountability. Information managers need to prove the worth of their services so that the parent institution acknowledges the impact of library and information services. The quality of the academic library could affect the overall quality of the institution.

\section{Service Quality}

Libraries are services and they exist to provide a service to the users who need it. Some basic principles are common to all quality measurements of services and also to library and information services. Quality of service is defined by the organisation's or customer's perception of both the quality of the product and the service providing it (Zeithaml, Parasuraman \& Berry 1990). Quality is linked to customer satisfaction, although quality for one customer or group of customers does not necessarily mean quality for another customer or group. A Working Group of IFLA on performance measurement agreed that "we must start performance assessment from the viewpoint of the user..." (Te Boekhorst 1995: 278).

Zeithaml, Parasuraman and Berry (1990) developed the Gap Analysis Model (Figure 1), based on substantial research amongst service providers. This model shows how a perceived service can diverge from actual delivered service and this can assist to identify gaps and causes of poor service, which could affect quality.

Figure 1: Gap Analysis Model: Factors affecting service quality

\section{Gaps model of service delivery}

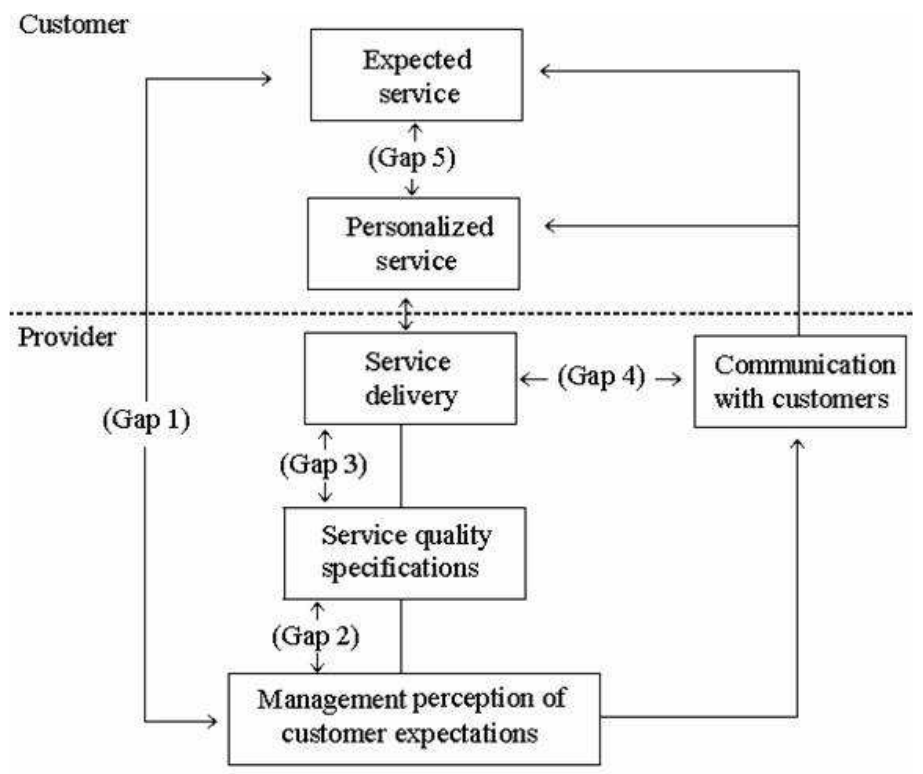

(Zeithaml, Bitner \& Gremler 2006: 46)

This model highlights five gaps in service delivery (Zeithaml, Parasuraman \& Berry 1990; Zeithaml, Bitner \& Gremler 2006: 32-46): 
1. Provider Gap 1: Not knowing what customers expect and desire. The key reasons for this gap, are a lack of marketing research, inadequate upward communication, and too many levels of management. To close these gaps, customers' expectations should be researched, marketing research findings be used effectively, interaction between management and customers be increased, upward communication from contact personnel to management be improved, and the number of levels between contact personnel and management be reduced. Managers should understand what are the most important to customers. Communication from management to employees and between staff and customers is necessary to obtain relevant information on the service.

2. Provider Gap 2: Wrong service quality designs and standards. This gap occurs when there is inadequate commitment to service quality, a lack of perception of feasibility, inadequate task standardisation and an absence of goal setting. Quality service requires commitment and strong leadership from top management, as well as from middle management levels. Staff should believe that customer's expectations are feasible - the organisation or institution should have the capabilities to meet requirements for service in terms of finances, operating systems, resources and staff. Operating procedures and standardising some aspects of the service tasks can provide consistent service quality. With clear and specific goals for customer service, performance can be measured against these goals. These goals should be based on customers' requirements and expectations.

3. Provider Gap 3: Service-performance gap. This gap arises when organisational policies and procedures are in place, but staff is not following them. Staff may be unable or unwilling to deliver the service. This gap is the difference between organisational service specifications and actual levels of service delivery.

4. Provider Gap 4: Promises do not match delivery. Customers will perceive low-quality service when the service promised do not match the service that is actually delivered. Inadequate communication on various levels (for example advertising and public relations) can be responsible for this gap.

5. The consumer gap (Gap 5): These four provider gaps contribute to the consumer gap - the difference between expectations and perceptions of customers and the service delivered by the provider.

"The key to delivering high quality service is to continually monitor customer perceptions of service quality, identify causes of service quality shortfalls, and take appropriate action to improve the quality of service (close the gaps) "'(Zeithaml, Parasuraman \& Berry 1990).

Measuring quality in non-profit, service-oriented institutions is not as highly developed as in the profit sector, and libraries often do not attend to performance measurement (Petr 2007:170,174.). The quality of many libraries has never been really measured or questioned.

Although many libraries have not assessed their performance quality explicitly, they have often evaluated their services and user satisfaction on a small scale.

\section{Quality metrics in academic libraries}

There is no universal definition of what quality is. The ISO 9000 (2005) standard describe quality as "the consistent conformance of a product or service to a given set of standards or expectations". According to the ISO Standard 11620 Performance indicators for libraries, "quality" is the "totality of features and characteristics of a product or services that bear on the library's ability to satisfy stated or implied needs" (ISO 11620, 1998). Quality and effectiveness often implies the same.

In the $20^{\text {th }}$ century the focus was strongly on quantitative measurements such as the number of items in stock, the use thereof, number of visitors and reference requests. Measurements were traditionally library-focused rather than institutionally focused. A paradigm shift characterises the 21 st century, as user's expectations, technology, measurements, and many other library scenarios have changed. The library has a more expansive role and measuring quality is broader. The focus is strongly on user expectations and needs. The shift is "from measuring what you can count to measuring what counts" (De Jager 2004). This implies qualitative measurement, which is fundamentally subjective. 
According to Phipps (2001: 365), the purpose of gathering service quality data should be to identify what is working well and what is not and to increase knowledge of customer requirements.

The Northumbria International Conference on Performance Measurement in Libraries and Information Services is a highly successful biennial conference organized since 1995 within Northumbria University, Newcastle upon Tyne, United Kingdom. The focus is on librarians, information professionals, museum curators and records managers leading and developing the measurement and monitoring of performance in their institutions.

Various research studies were carried out to assess performance in academic libraries, with the aim to highlight different factors that could affect the perceptions of quality of academic libraries services, to name a few:

A number of studies have been done in the United Kingdom and Europe. In a report on assessment of academic libraries, "The effective academic library" the Higher Education Funding Council for England (1995), provided a model for the assessment of performance:

$>$ Integration level between the mission, aims and objectives of the institution and those of the library

$>$ User satisfaction with overall service provision and specific key services

$>$ Delivery: Objectives of the specific institution met and volume of output

$>$ Efficiency: Relating service provision to resource inputs

$>$ Economy: Overall costs, operating costs.

(Winkworth 2001:722).

Snoj and Petermanec (2001) investigated Slovenian academic libraries and identified the following dimensions that could affect the perceived quality of library services:

$>$ The library collection;

$>$ the physical surroundings of the library;

$>$ equipment and information technology;

$>$ library and information services;

$>$ library staff.

According to a report on Malaysian agricultural libraries, Majid, Anwar \& Eisenschitz (2001), the factors that affected the perceived quality are:

$>$ The provision of current literature;

$>$ the adequacy of the library collections;

$>$ the involvement of the respondents in selecting material for the library;

$>$ the adequacy of library equipment;

$>$ the adequacy of the physical facilities in the library;

$>$ library skills of the users;

$>$ frequency of library visits;

$>$ the location of the library;

$>$ the adequacy of the library promotion;

$>$ the availability of needed materials;

$>$ the availability of library assistance.

A project in Poland "Performance analysis for Polish research libraries" is focused on the development of methods and standards for the evaluation of quality of research and academic libraries (DerfertWolf, Gorski \& Marcinek 2005).

A project to evaluate Croatian academic library services (Petr 2007), is a good example of using both quantitative and qualitative measurement, although they did not include library users. A short questionnaire for library staff, an extended questionnaire for library directors or chief librarians, interviews with library directors or chief librarians, and the analysis of library documentation are the survey instruments.

In the United Kingdom, the Standing Conference of National and University Libraries (SCONUL) initiated a User Satisfaction Project to develop a standard nationally used user satisfaction assessment method (Winkworth 2001: 729). It is an easy to use questionnaire composed entirely of tickboxes to permit machine reading, with questions on how successful users were in using particular services, how 
satisfied they were, how important particular services were, whether expectations had been met, use of other libraries, and satisfaction and importance overall.

The most important international set of performance indicators and standards are the ISO standard on library performance indicators - ISO 2789 (2006) and ISO DIS 11620 (2006) and the IFLA guidelines for performance measurement in academic libraries. These IFLA indicators are: resources and infrastructure, use, efficiency, and potential and development (Poll \& Te Boekhorst 2007):

A. Resources, infrastructure: What services does the library offer?

\begin{tabular}{|l|l|}
\hline $\begin{array}{l}\text { Library as place for learning and } \\
\text { research }\end{array}$ & A.1. User area per capita \\
\hline & A.2. Seats per capita \\
\hline & A.3. Opening hours compared to demand \\
\hline Collections & A.4. Expenditure on information provision per capita \\
\hline & A.5. Availability of required titles \\
\hline & A.6. Percentage of rejected sessions \\
\hline & A.7. Ratio of requests received to requests sent out in interlibrary lending \\
\hline Staff & A.8. Immediate availability \\
\hline Website & A.9. Staff per capita \\
\hline & A.10. Direct access form the homepage \\
\hline
\end{tabular}

\section{B. Use: How are the services accepted?}

\begin{tabular}{|l|l|}
\hline General & B.1. Market penetration \\
\hline & B.2. User satisfaction \\
\hline Library as place for learning and research & B.3. Library visits per capita \\
\hline Collections & B.4. Seat occupancy rate \\
\hline & B.5. Number of content units downloaded per capita \\
\hline & B. 6. Collection use (turnover) \\
\hline & B.7. Percentage of stock not used \\
\hline Information services & B.8. Loans per capita \\
\hline & B.9. Percentage of loans to external users \\
\hline Cultural activities & B.10. Attendance at training lessons per capita \\
\hline & B.11. Reference questions per capita \\
\hline & B.12. Attendance at events per capita \\
\hline
\end{tabular}

\section{Efficiency: Are the services cost-effectively?}

\begin{tabular}{|l|l|}
\hline General & C.1. Cost per user \\
\hline & C.2. Cost per visit \\
\hline & C.3. Cost per use \\
\hline Collection costs & C.4. Ratio of acquisitions costs to staff costs \\
\hline & C.5. Cost per document processed \\
\hline Processes - speed & C.6. Cost per download \\
\hline & C.7. Acquisition speed \\
\hline & C.8. Media processing speed \\
\hline & C.9. Employee productivity in media processing \\
\hline & C.10. Lending speed \\
\hline Processes - reliability & C.11. Interlibrary loan speed \\
\hline & C. 12. Reference fill rate \\
\hline & C.13. Shelving accuracy \\
\hline
\end{tabular}

D. Potentials and development: Are there sufficient potentials for future development?

\begin{tabular}{|l|l|}
\hline Electronic services & $\begin{array}{l}\text { D.1. Percentage of acquisitions expenditure spent on } \\
\text { the electronic collection }\end{array}$ \\
\hline Staff development & $\begin{array}{l}\text { D.2. Percentage of library staff providing and } \\
\text { developing electronic services }\end{array}$ \\
\hline Budget & D.3. Attendances at training lessons per staff member \\
\hline & $\begin{array}{l}\text { D.4. Percentage of library means received by special } \\
\text { grants or income generation }\end{array}$ \\
\hline $\begin{array}{l}\text { D.5. Percentage of institutional means allocated to } \\
\text { the library }\end{array}$ \\
\hline
\end{tabular}


Quality in academic libraries can have many aspects. Measuring service quality in academic libraries could thus include the following areas:

1. Resources (information content): The quality of the collection could determine the quality of information support to teaching, learning and research.

- $\quad$ Relevance of documents and items available in the library

- Access to information sources - document delivery, catalogue

- $\quad$ Access to accredited academic journals - subscription or licensing

- Electronic document delivery: Electronic materials and electronic access to information

- $\quad$ Balance between holdings and access, and balance between print and electronic materials

- Open access

- Institutional repositories, for example technical reports, theses, dissertations and academic articles can be an indication of the research input and output of the institution

- $\quad$ Special collections and rare items

2. Management and Organisation (service environment and resource delivery). Commitment of the library management team to create an encouraging work environment. Management should be prepared to change decisions and procedures in order to improve service quality.

- Information strategies: Policies (for example a collection development policy) and procedures to the provision and management of information. According to the Follett Committee in the United Kingdom (Brophy 2000: 31), this would include the acquisition, creation, management and use of information, as well as information relationships with external agencies.

- $\quad$ Space and space management: buildings and facilities (such as printing and photocopying,), storage and study space, reading areas.

- Information technology and network connections available to users, as well as library management systems for basic operations like acquisitions, cataloguing and circulation.

- General appearance - notices, signage, posters, tidy shelves, furniture, appearance of staff - should be inviting. (You never have a second chance to make a first impression)

- $\quad$ Marketing of the library and its services - what the library has to offer. (marketing $=$ visibility)

- Professional involvement in selection and acquisition.

- Library expenditure, although it is not so easy to measure costs, for example how do you measure "value for money"? The total library budget - for example library materials, electronic access, network infrastructure, buildings, personnel, other overhead costs - should be measured to determine return on investment.

- User education

- Retrieving of information

- $\quad$ Reference and enquiry services

- $\quad$ Liaison between the library staff and teaching staff

- Co-operation between libraries, for example consortia.

3. Staffing and staff management: Staff is responsible for delivering services to the users. They are on the front line with customers. Strong management and leadership play an important role in delivering services. However, every employee in the institution must share the responsibility to contribute to quality. Improved service performance could be the result of staff commitment to service quality.

- $\quad$ Staff attitude - knowledgeable, enthusiastic, approachable, helpful staff - is a key ingredient of performance excellence

- Staff skills, qualifications, training and development, further education, workshops and conferences

- Performance management and reward systems to provide feedback on performance 
- Staff involvement in planning and decision making. Teamwork encourages shared responsibility.

When measuring quality in academic libraries, the needs and expectations of all the different stakeholders and users should be taken into account. The majority of users are full-time academic and non-academic staff, undergraduates and postgraduates. There are multiple stakeholders with different priorities and performance measure requirements: end-customers (students), service purchasers (academic departments, institutions), funding institutions (funding councils, government), guardians of quality (professional bodies), service managers, and staff (Winkworth 2001: 722).

Benchmarking between academic libraries is a means of assessing performance, apart from quality measurement in one's own institution. Benchmarking usually involves the following, according to Roberts and Rowley (2004:169):

- Regularly comparing performance with standards or best practices;

- Identifying gaps where performance falls below standards and comparators;

- Seeking out different approaches that can achieve improvements in performance;

- Implementing improvements;

- Monitoring progress with improvements and reviewing the benefits.

By comparing yourself with others, one can understand how they operate effectively and apply practices to one's own organisation.

\section{Quality and the digital environment}

With the development of information and communication technologies in the digital environment of the $21^{\text {st }}$ century, users have other needs and expectations from library services. (Who needs the library anymore? We have the Internet!). There is a move from collections to connections.

Since the mid-1990s, scientific publications began the transformation from print to electronic resources and libraries began to invest in e-resources. Users are often more interested in access to information than physical materials. Additional measures to evaluate the performance of digital library environments need to be developed, for example transaction logs on Weblogs reveal search strategies and use of digital documents.

The United States Association of Research Libraries (ARL) developed performance indicators for digital library environments, including accessible electronic resources, expenditures for networked resources, use of networked resources and services, and library digitization activities (Roberts \& Rowley 2004: 174). A number of other projects are working on e-metrics. The EQUINOX project combines a set of twelve electronic indicators with a software package which demonstrate the linkages between each indicator and library objectives (Winkworth 2001: 722). A study at the University of Illinois investigated the library's return on investment and the benefits of using electronics resources (Kaufman 2008). In this study more than $80 \%$ of respondents identified the following ways in which digital access had a positive impact on their work: Digital access allows them to dedicate less time to physical visits to the library, digital access allows scholarly information to be better integrated into their research workflow, and digital access allows them to make better use of literature in interdisciplinary and emergent fields of study.

\section{Methodology of quality measurement}

Quality assessment of an academic library includes products, services, individuals (users, staff, management), as well as the institution. Quality metrics of the service will have to include evaluations at an individual, service, and organisational level. Quality measurement means collecting statistical and other data that describe the performance of the library and analysing these data in order to evaluate the performance quality. Quality criteria are determined by the institution's requirements and the library's goals and objectives, as well as the users' needs and expectations.

To measure quality in academic libraries, one needs to investigate a common framework of reference, an agreed set of standards, performance indicators, evaluation criteria and methodologies. It is, however, important to take local conditions into account, as libraries have different missions and goals, collections and services, and countries may have different standards. Performance indicators will be determined by the specific institution and purpose of the specific measurement. 
$>$ Both qualitative and quantitative methods are necessary for measuring the library and its services.

Duantitative as well as qualitative data can be collected through questionnaires. A combination of closed (precoded) and open (free response) questions can be used. Quantitative data is easy to analyse, but open questions - qualitative data - need content analysis.

$>$ Quantitative statistical data - expressed in numbers - can show the state-of-the-art of the library, for example user data, collection size, management data, transactional usage data and financial expenditure.

$>$ Qualitative measures evaluate expectations, views, opinions, suggestions and are largely subjective. Methods for qualitative measures include surveys, interviews and discussion groups.

$>$ A simplistic summary of quantitative versus qualitative characteristics:

\begin{tabular}{|l|l|}
\hline Quantitative & Qualitative \\
\hline Breadth/mass data & Depth/smaller samples \\
\hline Objective & Subjective \\
\hline "Scientific" & "Non-scientific" \\
\hline Highly structured approach & Looser approach \\
\hline Answer "how often"/how much" - statistical & Answer "why" - causative \\
\hline Less helpful with complex topics & More helpful with complex topics \\
\hline Emphasis on neutrality & Emphasis on the actor's perspective \\
\hline Usually clear-cut precise results & Useful for preliminary work \\
\hline
\end{tabular}

(Morgan 1995: 138)

Performance statistical reports, monthly and annual reports, and other library documentation can be analysed.

$>$ It is important to involve different user groups in the academic library in performance evaluations. Different evaluations, expectations and perspectives are needed to measure the quality of the library and information services.

$>$ Specific surveys on a large scale can measure user satisfaction directly, although they can be time-consuming and costly. Instruments such as SERVQUAL and LibQUAL are valuable tools in measuring library service quality.

Zeithaml, Parasuraman \& Berry (1990) developed SERVQUAL, a general instrument for measuring customer's perceptions of service quality. They identified five general service quality dimensions which contribute to consumer expectations and perceptions of service quality (Zeithaml, Parasuraman \& Berry 1990: 26):

$>$ Tangibles: Appearance of physical facilities, equipment, personnel, and communication materials;

$>$ Reliability: Ability to perform the promised service dependably and accurately;

$>$ Responsiveness: Willingness to help customers and provide prompt service;

$>$ Assurance: Knowledge and courtesy of employees and their ability to convey trust and confidence;

$>$ Empathy: Caring, individualized attention the firm provides the customers.

Many libraries adapted SERVQUAL as instrument to measure service quality.

LibQUAL is a joint project of Texas A\&M University and the Association for Research Libraries in the United States that enables institutions to address service quality gaps and to enhance responses to user needs. The dimensions of LibQUAL are:

$>$ Affect of service: The human side of the institution - empathy, accessibility and personal competence;

$>$ Personal control: The extent to which users are able to navigate and control information that is provided;

$>$ Access to information: The adequacy of the collections themselves and the ability to access needed information on a timely basis;

> Library as place: Comprising utilitarian space for study and collaboration.

(Roberts \& Rowley 2004: 16)

Services can be rated formally through surveys, meetings and interviews with library staff and users. Academic libraries often have formal library committees to advise library management. 
Services can also be rated more informally through a suggestion box, complaints box, electronic channels and informal communication with library staff and users. Staff can keep record of informal complaints or suggestions that users make. Staff at the front-line of service delivery will be aware of gaps in the service and user dissatisfaction.

$>$ Ongoing liaison between library staff and groups of users could monitor user satisfaction (Brophy 2000: 65). An annual user satisfaction survey on a smaller scale can give users the opportunity to comment on the service.

$>$ Performance measures may rate the overall performance of the service, or certain aspects of the service.

It is necessary to review performance measures from time to time and to make adjustments and other changes when needed.

\section{Conclusions}

Quality in academic libraries is a multi-dimensional construct. Performance measurement is part of a broader quality framework. Quality assessment is done from the perspective of different groups of people. Both quantitative and qualitative measurements are required to determine the quality and effectiveness of the library. Quality measurement is a recurrent process and quality metrics in academic libraries should be done with appropriate frequency in order to keep up with constant change, new demands (e.g. post-graduates), trends and developments (e.g. electronic resources and technology).

According to a project in Croatia to measure quality in public and academic libraries, "Insufficient awareness to library service quality affects all library processes, and ultimately leads to deterioration of that service quality" (Petr 2007: 174).

It is of utmost importance that all stakeholders are aware of the value and importance of quality metrics as a tool to strive for excellence and to enhance quality. What are we doing? Why are we doing that? What matters? Where are we failing and how can we close the gaps?

The ultimate goal of measurement is improving the "fitness for purpose" of the library and to enhance quality. The academic library is a role player in higher education effectiveness. Leadership and good management are needed, as well as involvement and commitment by all employees. Libraries are services and they need to re-examine the ways in which services are delivered continuously. It is the task of the academic library to move from a passive service provider to an active and vital force in the institution.

\section{References}

Blake, J. (2008). Education and quality metrics. Midrand: Midrand Graduate Institute.

Bologna Declaration of 19 June 1999: Joint declaration of the European Ministers of Education. European Higher Education Area. (1999). Available at: www.bologna-bergen2005.no/Docs/00

Main doc/990719BOLOGNA DECLARATION.pdf (Accessed 15 April 2009).

Brophy, P. (1997). Total quality management. In: Resource management in academic libraries. London: Library Association Publishing.

Brophy, P. (2000). The academic library. London: Library Association Publishing.

De Jager, Karin. (2005). Counting what matters: To measure what counts. Paper: Getting beyond the starting blocks: Quality assurance issues in academic libraries. Stellenbosch: University of Stellenbosch.

Derfert-Wolf, L., Gorski, M.M. \& Marcinek, M. (2005). Quality of academic libraries - funding bodies, librarians and user perspective: a common project of Polish research libraries on comparable measures. Proceedings: World Library and Information Congress: 71th IFLA General Conference and Council, August $14^{\text {th }}-18^{\text {th }}$, Oslo, Norway. Available at: www.ifla.org/IV/ifla71/Programme.htm (Accessed 16 April 2009).

EQUINOX. Library performance measurement and quality management system. (1998-2000). Available at: http://equinox.dcu.ie/index.html 
Haas, Andrine J. (2006). Assessment of library resources and services as part of the college program review process. In: It's all about student learning: Managing community and other college libraries in the $21^{\text {st }}$ century. 2006. Edited by David R Dowell \& Gerard B McCabe. Westport: Libraries Unlimited.

Haddow, G. (2007). Academic libraries and the research quality framework. Australian Academic and Research Libraries, 38 (1): 26-37.

Higher Education Funding Council for England. (1995). The effective academic library: a framework for evaluating the performance of UK academic libraries. Bristol: HEFC.

ISO 11620. (1998). Information and documentation. Library performance indicators. Geneva: International Organization for Standardization.

ISO DIS 11620. (2006). Information and documentation. Library performance indicators. Geneva: International Organization for Standardization.

ISO 2789. (2006). Information and documentation. International library statistics. Geneva: International Organization for Standardization.

ISO 9000. (2005). Quality management systems, fundamentals and vocabulary. Geneva: International Organization for Standardization.

Kaufman, Paula T. (2008). The library as strategic investment: results of the Illinois return on investment study. Liber Quarterly, 18 (3/4). Available at: http://liber.library.uu.nl/publish/articles/000269/article content.htm. (Accessed 16 February 2009).

LibQUAL+TM. Available at: http://www.libqual.org/

Majid, S., Anwar, M.A \& Eisenschitz, T.S. (2001). User perceptions of library effectiveness in Malaysian agricultural libraries. Library Review, 50 (4): 176-187.

Morgan, Steve. (1995). Performance assessment in academic libraries. New York: Mansel.

Petr, K. 2007. Quality measurement of Croatian public and academic libraries: a methodology. Performance measurement and metrics, 8 (3): 170-179.

Phipps, Shelley. (2001). Beyond measuring service quality: learning from the voices of the customers, the staff, the processes, and the organization. Library Trends, 49 (4): 635 - 661.

Poll, R. \& Te Boekhorst, P. (2007). Measuring quality: performance measurements in libraries. The Hague: International Federation of Library Associations (IFLA).

Pritchard, S.M. (1996). Determining quality in academic libraries. Library Trends, 44 (3): 572-595.

Roberts, S \& Rowley, J. (2004). Managing information services. London: Facet Publishing.

Snoj, B. \& Petermanec, Z. (2001). Let users judge the quality of faculty library services. New Library World, 102 (1168): 314-325.

Te Boekhorst, P. (1995). Measuring quality: The IFLA guidelines for performance measurement in academic libraries. IFLA Journal, 21(4): 278-281.

Winkworth, Ian. (2001). Innovative United Kingdom approaches to measuring service quality. Library Trends, 49 (4): 718-731.

Zeithaml, Valarie A., Parasuraman, A. \& Berry, Leonard L. (1990). Delivering quality service: Balancing customer perceptions and expectations. NewYork: Free Press

Zeithaml, V.A, Bitner, M.J. \& Gremler, D.D. (2006). Services marketing: Integrating customer focus across the firm. Boston: McGraw-Hill. 